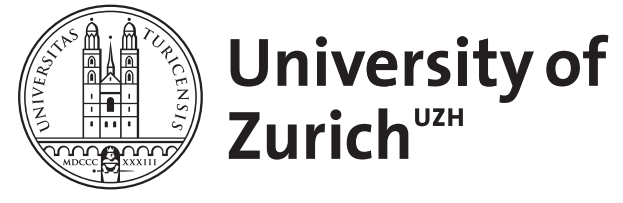

\title{
The dialectology of Germanic
}

Rübekeil, Ludwig

Posted at the Zurich Open Repository and Archive, University of Zurich ZORA URL: https://doi.org/10.5167/uzh-148822

Book Section

Published Version

Originally published at:

Rübekeil, Ludwig (2017). The dialectology of Germanic. In: Klein, Jared; Joseph, Brian; Fritz, Matthias. Handbook of comparative and historical Indo-European linguistics. Berlin, Boston: De Gruyter, 9861002. 


\section{The dialectology of Germanic}

1. Dialects and historiography

2. Dialects in the earliest evidence

3. Dialects and language grouping
4. Abbreviations

5. References

\section{Dialects and historiography}

\subsection{Tribal history}

Several literary sources of Antiquity describe the subdivision of the Germanic tribes, but they do it in different ways: Pliny lists five subgroups and in some cases he also mentions their seats as well as single tribal names belonging to these groups. The groups are called Vandili, Inguaeones, Istuaeones (near the Rhine), Hermiones (in the inner lands) and Peucini Basternae (near the Dacians, i.e. near the lower Danube/Black Sea). The Vandili, who from other sources are known to have lived in the east of the Gmc area, consist of the Burgodiones, Varinnae, Charini, Gutones, names which are likewise attested in the east. The Inguaeones include the Cimbri, Teutoni, and Chauci, tribes which were supposed to have lived near the North Sea; and the Suebi, Hermunduri, Chatti, and Cherusci belong to the Hermiones. For the Istuaeones and Peucini Basternae there are no further names mentioned.

Tacitus, half a century after Pliny, mentions only three subgroups: Ingvaeones, Istvaeones and Herminones. His account puts the names in a mythical context by tracing them back to the names of three eponymous ancestors, who in their turn are sons of Mannus 'man'. Tacitus is aware, however, that this grouping of the Gmc tribes is not fully accepted and quotes another (anonymous) view of Gmc grouping with entirely different names, i.e. Marsi, Gambrivii, Suebi and Vandilii. The importance of this alternative grouping is corroborated by the statement that the latter names are the "true and old names" (vera et antiqua nomina). The most interesting fact is, however, that the earlier attested story of Pliny appears to be a synthesis of the two competing versions by Tacitus.

The accounts of Pliny and Tacitus have had much influence on how the history and language of Gmc peoples have been looked upon up to modern times (cf. 3.1). The earliest written sources about Germanic peoples rarely deal with language, but usually with tribal history and culture. This has had consequences for the dialectology of the Germanic languages insofar as scholars, too, have confounded historical, archaeological and linguistic data. Therefore, several theories of Germanic dialect grouping are strongly influenced by those accounts, some of them being even modified or interpreted versions of ethnic arrangements in ancient literature. Many linguistic theories, on the other hand, were rejected because of their seeming incompatibility with historical data (cf. Nielsen 1985: $11 \mathrm{ff}$.). Moreover, dialectal concepts based on the accounts of Pliny and Tacitus had another problem, namely that their groups only seemed to comprise continental peoples. Both Pliny and Tacitus mention some Scandinavian tribes, but they do not integrate them into their schemes of ethnic relationship. This became an issue for all models that relied on ethnographical information (cf. 3.1). 
There are also other authors who mention some kind of grouping or relationship of Gmc tribes, but not as explicitly as Pliny or Tacitus. Some of these statements make their fictitiousness very obvious; Ammianus Marcellinus, for instance, notes that the Burgundians themselves believed that they had originated from the Romans. It is not until the beginning of the Middle Ages that some sources write in depth about the origin and filiation of certain tribes, as for instance the Scandinavian origin of the Goths (Jordanes) and the Langobards (Origo gentis Landobardarum, Paulus Diaconus). These stories, however, are not very reliable and, sometimes, they may be considered more or less pointless fiction.

\subsection{Methodological aspects}

The Goths played an important role in ancient historiography from ca. $100 \mathrm{CE}$ onwards. The Gothic bible translation dating from about 300 years later is ascribed to a small part of the Visigoths called Gothi minores 'smaller Goths' (the Visigoths themselves being a tribal branch of the Goths), but was later on taken over by all Gothic peoples. Therefore, we can conclude that the Gothi minores - minorities subtracted - had a common language, and the Gothic peoples of the $5^{\text {th }}$ century spoke dialectal variants of the same language, which is quite legitimately called the Gothic language. Problems arose when earlier generations of philologists applied this idea to tribal entities without extensive attestations of their language, reconstructing a family called East Gmc which included all neighbouring tribes (and thus languages). The East Gmc character of Burgundian and Vandalic, for example, while plausible, is still a subject of controversy (cf. 3.5). It is even more problematic to postulate a specific Marcomannic or Semnonic language for tribes called Marcomanni or Semnones. The problem persists if we combine diachronic and diatopic evidence. The name Langobardi, for example, is attested around the lower Elbe near Hamburg in the $1^{\text {st }}$ century CE; in the following centuries, this tribe migrated through Eastern Europe until they invaded Italy in $568 \mathrm{CE}$. In many respects the few attested Langobardic words (most of them from about 1-2 centuries after the invasion of Italy) are quite similar to $\mathrm{OHG}$, but they lack some specific OHG features.

On the basis of the early tribal seats, some scholars attributed the Langobardic language to Ingvaeonic (North Sea Gmc), others, however, to Erminonic (Elbe Gmc). The obvious linguistic relationship with $\mathrm{OHG}$, on the other hand, was partly explained as common heritage of Elbe Germanic, whereas others considered it as a result of a secondary OHG-Lang. "sprachbund". The fact that they had for a while been neighbours of East Germanic tribes, such as the Goths and Gepids, left its marks especially on proper names; yet some scholars even considered Langobardic to be a genuine East Gmc dialect. Their opponents emphasized its North Gmc features and referred to medieval records which claimed Scandinavia as the original homeland of the Langobards (for this discussion cf. Bruckner 1895: 24 ff.; Frings 1932: 32; Maurer 1952: 49 ff.; Schwarz 1951: 233 ff.; Kuhn 1955: 1 ff.). 


\subsection{Gmc language in ancient sources}

If language becomes an issue, ancient sources usually talk about "the Germanic language", which as a uniform entity seemed to be easily recognizable and was distinguished from non-Gmc languages. Internal variation seemed to be of little interest. Furthermore, most authors (and their sources) obviously did not know enough about the Gmc language to be good judges. Therefore, scholars hesitate to believe that the dialect of the Aestii, who belonged to the Gmc subgroup Suebi and whose name lives on in modern Estonian, was similar to the Brythonic language (lingua Britannicae proprior), as Tacitus claims. Rather, it is considered to be a Finnish or Baltic dialect. If there are any hints of dialectal differences at all, they are very well hidden: Tacitus' statement about the Marsigni and Buri, who according to their language and culture belong to the Suebi (and not to the Germani), has been interpreted as referring to a subgroup of the Germanic language. Similarly, he groups the Canninefates on the Lower Rhine with the neighbouring Batavians (and not the Germani) on account of their language (besides their virtue and origin), which might indicate a dialect of Germanic. The evidence, however, is slender.

Moreover, the fact that in some cases very important linguistic differences were not noticed at all highlights the danger of relying on such kind of evidence. The Cimbrians are usually counted among the Germanic tribes - also by Pliny. Yet, he claims that the Cimbrian name for the 'dead sea' in the North is Morimarusa, which indeed means 'dead sea', but in Gaulish, not Germanic. Pliny also states that the word sapo 'soap' (*saipjo-) is Gaulish, although it is most probably Gmc (cf. 2.2).

From the migration period onwards, there is more evidence available, but even then it is often unclear what linguistic entities the sources refer to. For example, Agathias enigmatically claims that in former times the Francs were well known under the name of Germanoi, but that in his own time they only distinguish themselves from the Romans by their "strange language". Agathias seems to include different tribes under Franconian rule. According to Procopius, all "Gothic tribes" (mainly, but not only, Goths, Vandals, Visigoths and Gepids) only differ in their names, and they have the same language, too, which is called the "Gothic language". It would be daring, though, to conclude from this an EGmc entity.

\section{Dialects in the earliest evidence}

\subsection{Proto-Gmc as an IE language}

Gmc belongs to the Western group of IE languages and differs clearly from related language groups such as Italic or Celtic. To this day no agreement has been reached about the question as to where Gmc should be located within the IE family tree, since its historical neighbour languages, i.e. Celtic, Italic, Slavic, and Baltic, are not always regarded linguistically as its closest relatives. Furthermore, the question of what should be considered the main distinctive characteristic of Germanic is debated. The First Consonant Shift (Grimm's Law) has often been regarded as such a defining criterion, but it probably is only the most obvious one, as it affects often-quoted etymologies like Latin 
pater vs. English father. Other changes have altered the appearance and especially the system of Gmc much more profoundly (Ringe 2006: 67 ff.).

Important phonological changes are:

- Grimm's Law

- Verner's Law

- Loss or vocalization of laryngeals

- Vowel merger $\partial, a, o>a$ and $\bar{a}, \bar{o}>\bar{o}$

- Svarabhakti: $r, l, m, n>u r, u l, u m, u n$

Accent fixation on the first syllable or stem syllable, respectively Important morphological changes include:

- Weakening and partial loss of non-initial and especially final syllables

- Incipient convergence of nominal classes, some even disappearing before the transmission of Goth

- Heavy reduction of the categories of verbal inflection

- Emergence of a weak preterite with dental suffixes

One aspect in which Gmc has conserved IE structures quite well is the ablaut system of the strong verb: the present tense primarily continues the IE thematic (non-reduplicated) present stems; the past tense or preterite of the Gmc strong verb, on the other hand, preserves basic structures of the IE perfect.

Gmc has sometimes been referred to as a homogeneous proto-language, which only split up into various dialects at a later time. In view of the data, however, this is rather unlikely, since there are traces of old dialectal differences. There are two principal explanatory models for the historical relationship of languages: the family tree model of August Schleicher and the wave model of Johannes Schmidt. The family tree only considers the genetic background of language history; the wave model, on the other hand, focuses on geographical proximity and linguistic interference between the Gmc subgroups (cf. van Pottelberge 2003). The most adequate way of applying these conceptualizations today is to combine the family tree as a model for visualizing relationship and the wave model for explaining secondary convergence. These two can be complemented by a third mechanism, which is called drift, the phenomenon whereby parallel linguistic processes often appear in genetically related languages subsequent to their separation, apparently owing to their common past. This aspect was elaborated into the so-called "Entfaltungstheorie" (Höfler 1955-1956). Umlaut processes or Auslautgesetze, for instance, occur in the individual languages but are often regarded as consequences of the accent shift. It has always been one of the central problems of Germanic dialect grouping that such models were confused with historical reality; however, they do not explain but only visualize.

\subsection{Gmc names and words in ancient literature}

The earliest attested records of the Gmc language are words and proper names in classical literature, some of which give indications of Gmc phonology or morphology and can often be linked to lexical units of later times. Some of these items may be traced back 
to the Greek seafarer Pytheas, who undertook a journey to the North Sea in the $4^{\text {th }}$ century BCE. Definite evidence, however, begins in the $1^{\text {st }}$ century BCE, when the Romans, beginning with Caesar, established a common border with Germanic-speaking peoples. Some examples of early recorded appellative words are (Green 1998: $182 \mathrm{ff}$.):

alcis 'kind of a stag': *alhiz (?) this word is related but probably not identical to ON elgr (<*algiz, showing Verner's Law) and OHG elahho <*elhōn-. The singular form of this word is perhaps preserved in the title of an East Gmc priest, Alci(s), which is recorded by Tacitus. As in Latin, the Gmc word might be an $i$-stem which would make it closest to the ON cognate.

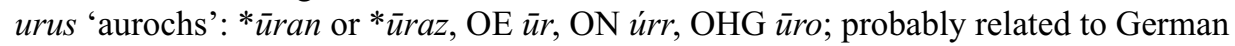
Auer(-ochs).

bruta or brutes 'bride' (in several inscriptions): probably a loanword from Gmc *brūdiz 'bride' as in Goth brups, OE brȳd, OS brūd, OHG brūt, ON brúdr, all meaning 'bride, young woman'; heavily influenced by Latin morphology.

glesum or glaesum 'amber': *glēzan as in MLG glār 'resin' and perhaps OE gloer 'amber'; most of the younger cognates continue a variant *glasa- without Verner's Law and without long-grade ablaut vowel.

sualiternicum 'amber': is probably a mistake for *sualitervium, the Gmc form of which is *swali-terwjan 'burn-resin' (Neumann 1993). The first element *swali- contains a verbal stem which is continued in OE OHG swelan 'burn, glow'. The second element *terwja- is derived from the Gmc word for 'wood', *teru- (cf. NE tar).

sapo 'hair dye': obviously mistaken from Gmc * saip(j)ō (thus the early Finnish loanword saipio) which is continued in OE sāpe, OHG sei(p)fa 'soap'.

ganta 'goose': *gantan- as opposed to *gans(i/u)- of most of the Gmc languages (OHG gans, OE OFr. gōs).

framea 'spear': this might be a derivation *fram-ja- (a pertinentive derivative of the preposition *frama 'forward, from'), but more likely a compound *fram-ij-an- 'forward going one' (with IE * $h_{1} e i$ - 'go' as second element). In either case, a corresponding verb seems to be continued in ON fremja, OHG fremmen, OS fremmian 'carry out' $<*$ framjana-. Semantically, the word is fully comparable to forms found in runic inscriptions like those from Øvre Stabu (raunijaz 'tester'), Kowel (tilarids 'goal rider') or Dahmsdorf (ranja 'runner'), some of which seem even similar from a morphological point of view.

At least as relevant (and more frequently attested) are proper names, such as personal, tribal, and place names, which give us some insight into the structure of early Gmc. Such information, however, can be misleading, as it depends on assumptions (e.g. on etymology) which often are as uncertain as the desired result. Altogether, these words and names indicate that at least the phonology and most probably the (nominal) morphology as well remained on the level of Proto-Gmc. Yet, as most of these words are recorded in Latin texts, Latin interference in phonology and morphology has to be taken into consideration.

Consonants: The early texts already show the Gmc Consonant Shift as, for example, in Harigasti, Chariovalda, Harii, Charini (< IE *korio-, *korino-) and Verner's Law as in Venadi (< IE *uenHtó-?), the latter perhaps with vocalization of the laryngeal as well (cf. however Müller 2007: $147 \mathrm{ff}$.). Svarabhakti of IE resonants turns up fully developed (Burgundii $\left.<* b^{h} r g^{h}{ }_{0} t-\right)$, but the loss of nasals before $h(V n h>V: h)$ does not seem to be completed yet, as the tribal name Tencteri is usually interpreted as Gmc *Penhterōz 
(concerning -anh- in the Burgundian personal name Hanhavaldus cf. 3.5). Since the $4^{\text {th }}$ century ethnic name Salii $<{ }^{*}$ Saljozz shows no traces of WGmc. gemination, it seems likely that this sound change was not completed before the end of the $4^{\text {th }}$ century (Wagner 1989; cf. however 2.3. [kunni]). Furthermore, there are no traces of rhotacism during the Roman Imperial Age.

Vowels: IE $o>a$ has been completed everywhere with the exception of the thematic vowel in composition, often in connection with a second element starting with a labial (e.g. Lango-bardi < PIE * dlong ${ }^{h} o-$; but cf. Marchand 1959: 172 f.). On the other hand, Gmc $e$ is preserved in all positions, even before $i, u$ and $n C$, and Gmc $i$ as well as $u$ are not lowered before $a$ ( $a$-umlaut). Proto-Gmc $\bar{a}$ might still be preserved in Caesar's silva Bacenis (if this relates to OS OE bōc, OHG buohha 'beech'; cf. Lat. fāgus), and the lowering of Proto-Gmc $\bar{e}_{1}$ to $\bar{a}$ cannot be dated before the $3^{\text {rd }}$ century (Lat. Suebi $\sim$ Gmc ${ }^{*}$ Swe $\bar{e}_{1} b \bar{o} z$; Lat. Inguiomerus $\sim \mathrm{Gmc}{ }^{*}$ Ingwjame $_{1}$ ri/jaz; cf. 3.2).

Morphology: It is difficult to judge morphology from Gmc words in ancient sources, as in most cases the inflection of foreign names follows the rules of Latin (or Greek) grammar. Therefore, it is quite unclear how much one can trust a Latin $n$-stem, for example, to indicate a Gmc $n$-stem (it is certain in Gutones = Gmc *Gutanez 'Goths'; cf. Pietroassa gen. pl. gutani Biblical Goth gutane). In some cases, however, Gmc tribal names are recorded with alternating inflectional stems in - $n$ - and -o-, which perhaps reflects an alternation of Gmc $n$ - and $a$-stem inflection (Burgundii : Burgundiones, Lugii : Lugiones, Franci : Francones). The etymology of these names points to adjectives or participles (*burgund(ja)- 'being high'; *lugja- 'mendacious' or 'sworn [companion], confederate'; *franka- 'aggressive, bold'). The alternation very likely indicates that the Gmc double adjectival declension already existed. A specific problem is posed by masculine personal names in - a like Nasua, Catvalda, Chariovalda, which in turn have been interpreted as WGmc $a$-stems with loss of $-z$ or as $n$-stems; some scholars have even assumed masc. $\bar{a}$-stems as in Lat. poetā (cf. 3.2; for a discussion see Marchand 1959; Krause 1971: 19; Boutkan 1995: 49 f.; Nielsen 2000: 166 f.; and Reichert 2003).

Inscriptions from the Lower Rhine bear matron names, i.e. names of female goddesses (matronae) with partially Gmc etymologies (Mees 2006). The ending -ims on some of them, as for instance Aflims, Vatvims, alternates with the Lat. -iabus (Aflims vs. Afliabus) and has therefore been interpreted as a Gmc dat. pl. ending < PGmc *-imiz. If this is correct, these forms indicate that the loss of final $-z$ in WGmc is later than the $3^{\text {rd }}$ century (cf. however 2.3 and $3.3 \mathrm{f}$.), yet the evidence of $k a[\mathrm{~m}] b a<\mathrm{PGmc}$. *kambaz on the newly-found comb of Frienstedt (ca. 300) indicates loss of $-z$ before that date (Schmidt et al. 2011: $141 \mathrm{ff}$.).

\subsection{The early runic language}

The first texts written in Germanic are runic inscriptions concentrated in modern Denmark dating back to the $2^{\text {nd }}$ century CE. The language of these inscriptions is very close to Proto-Germanic. It is called Primitive Norse, Proto-Scandinavian or "Urnordisch", since it was originally thought to be the direct ancestor of the medieval and modern Scandinavian languages. This view, however, has been challenged in recent decades. The rather uniform character of this language attested from about 200 to 500 has raised 
the question as to whether the idiom of the early runic inscriptions might not be best regarded as a kind of a Koine (Makaev 1996). In comparison with Proto-Gmc, however, these inscriptions show some linguistic differences, most of which live on both in later WGmc languages and in Old Norse. The differences particularly concern the vowel system. Thus Gmc $\bar{e}_{1}$ appears as $\bar{a}$ in wajemariz (Thorsberg around $200 \mathrm{CE}$, as opposed to Goth wajamerjan 'blaspheme'). Unstressed Gmc ai partly becomes $\bar{e}$ as in tawide (Illerup, ca. 200) or woduride (a-stem dat. sg.; Tune ca. 400), but not in talgidai (Nøvling, $3^{\text {rd }}$ century) or hahai (Möjbro, $5^{\text {th }}$ century); but cf. Nedoma (2005). The ending of woduride matches $\mathrm{OHG}$ and $\mathrm{ON}-e$, but not OE (and partly OS) $-a$. Short $u$ is lowered to $o$ before mid and low vowels as in horna < PGmc *hurna (Gallehus ca. 400); and holtijaz, where $o$ is due to analogy with *holta, shows that $o$ must already have had phonemic status. Gmc $e$, on the other hand, is partly preserved before $u$ and $i$, cf. leugaz (Skåang, ca. 500), erilaz (several instances). Loss of nasals before $h$ might have taken place during this period, judging from records such as hahai (Möjbro). If the evidence is trustworthy, the specific Norse innovation of sharpening had not yet taken place (Krause 1971: $32 \mathrm{ff}$.). The first NGmc sound change to show up in runic inscriptions is the monophthongization of ai to $\bar{a}$ before $h$ in fahido 'I painted' (Rö, ca. 400) vs. older faihido (Einang, end of $4^{\text {th }}$ century).

Most of the attested forms could at the same time be predecessors of ON and of their WGmc equivalents. That is why the language of the runic inscriptions has been labelled North-West Gmc by some scholars since Kuhn (1955: $24 \mathrm{f}$.). There are even forms with counterparts in WGmc alone; for example, asugisalas (Kragehul, ca. 500) and godagas (Valsfjord, ca. 400), which form their gen. sg. in -as like the OE $a$-stems. Final $-z$ in unaccented position, on the other hand, very likely disappeared quite early in WGmc. or in some of its varieties, as shown above (2.2). In many runic word forms, however, it is well preserved, e.g. holtijaz, leugaz, erilaz. Others look as if the loss of final $-z$ had already taken place, for instance in alugod (Værløse, ca. 200), swarta (Illerup), lagupewa (Illerup), and perhaps even in harja (Vimose, ca. 160). Admittedly, all these cases are quite doubtful since they can be interpreted as neuters, as weak stems, or as non-nom. sg. forms (cf. Nielsen 2000: 149 f.; Looijenga 2003: 94 ff.; Kortlandt 2006).

In the weak declension, the ending of the masc. nom. sg. has often been regarded as an indicator of dialectal affiliation. Consequently, names with masc. nom. sg. forms in $-a$ were regarded as EGmc (Goth hana), - o as WGmc (OHG OS hano) and $-e$ or $-i$ as ON (OIc. hani); for a more recent attempt to explain this alternation within Proto Norse cf. Nedoma (2005). However, it is in many cases difficult to decide whether a name is masculine at all.

Clear WGmc evidence in the early runic corpus is rare: distinct features of WGmc such as the ending of the $2 \mathrm{sg}$. pret. (type OHG OS nammi vs. Goth ON namt) cannot be found in the early runic inscriptions; $j$-gemination, however, shows up in kunni (Weser bones, probably around 400; for a possible terminus post quem cf. 2.2[ Salii]). Obviously WGmc dialect variants can be found from the $6^{\text {th }}$ to the $8^{\text {th }}$ century in the Frisian, AngloSaxon and South Gmc corpus, the latter lasting for only a few generations during the $7^{\text {th }}$ century.

There are, however, obvious EGmc inscriptions with word forms that sometimes recall Biblical Goth structures like tilarids (Kowel, early $3^{\text {rd }}$ century) $<*$ tilarìdaz with syncope and "Auslautverhärtung", gutani Pietroassa (around 400; cf. 2.4). The EGmc character of other inscriptions is less certain, e.g. ranja (Dahmsdorf, $3^{\text {rd }}$ century). 


\subsection{Biblical Gothic}

Apart from the first few runic inscriptions and some proper names, Gothic is the earliest attested Gmc language, but its corpus is significantly larger than that of the runic inscriptions. It consists, above all, of the bible translation by the Visigothic bishop Wulfila $\left(4^{\text {th }}\right.$ century CE). Wulfila created a special script for that purpose, consisting of Greek and runic characters. Besides the bible, there are several smaller texts, fragments and even some runic inscriptions.

While Gothic is, in most respects, less conservative than the earliest runic language, it shows some more archaic features, especially with respect to the vowel system. Gothic preserves $\bar{e}_{1}$, for example, in the plural preterite of strong verb classes 4 and 5 as in nèmun, sētun 'they took, sat' (OS nämun, sātun), and there is no a-mutation (gulp 'gold' $<{ }^{*}$ gulpa- vs. NGmc WGmc *golpa-). Like runic, Gothic still keeps Gmc -z, whereas the medieval languages and probably the runic language after around 700 have $r$ (rhotacism). On the other hand, Goth underwent several innovations that characterize its appearance quite noticeably. Every PGmc $e$ became $i$ except before $r, h, h$, where it resulted in ai $[\varepsilon]$ (similarly $u>$ aú [o] / r,h,h). Even more conspicuous is the so-called sharpening (German Verschärfung), in which the semivowels $j$ and $w$ turned into ddj (twaddje gen. pl. 'of two' <*twajje) and ggw (triggwus 'faithful' < *triwwus). Word-final syllables are weakened by several processes, including syncope and devoicing of final fricatives (dags, gasts $<*$ dagaz, * gastiz); devoicing occurs also in syllable-final position; therefore, the results of Verner's Law are levelled in many cases (hausjan 'hear' $<*$ hauzjana-). Similarly, Thurneysen's Law causes voiced spirants in syllable-final position to become voiceless if the initial sound of a syllable is voiced and vice versa. Concerning morphology, a reasonable comparison between Gothic and early runic is not expedient since especially relevant forms are only poorly attested in the runic inscriptions.

By contrast, Gothic is the only Germanic language to have kept the dual inflection of the verb (Fritz 2011: $154 \mathrm{ff}$.), a synthetic passive (usually called medio-passive), a fully functioning $4^{\text {th }}$ class of weak verbs in -nan, as well as reduplication in the $7^{\text {th }}$ class of strong verbs. Furthermore, Gothic still has a vocative case in most noun stems. Syncope, on the other hand, makes the inflectional forms look quite "modern" in comparison with the older runic inscriptions for instance (Goth gasts vs. runic gastiz; cf. Van Bree 1998). There is one feature of the Gothic verbal system about which there is a strong controversy as to whether it is an archaism or innovation: the long pret. pl. endings -dedum, -dedup, -dedun of the weak preterite (Ringe 2006: 167 f.; Hill 2010).

\section{Dialects and language grouping}

\subsection{Tripartite subgrouping}

Secondary literature today usually describes an early tripartite grouping into North, West, and East Gmc. Tripartite genealogies, moreover, have had a long tradition since Antiquity and the Middle Ages and can also be found in biblical explanations.

The concrete tripartite model of the Gmc language family, however, was first introduced by Schleicher (1869: 91), the "creator" of the family tree model itself (cf. 2.1). It is 
interesting though that in the case of other IE subroups Schleicher had a strong "binary" component in his family tree (most nodes in his model break up into two branches). The tripartite grouping of Gmc is of course not only due to linguistic features, but also to the mythological genealogy reported by Tacitus (cf. 1.1). Linguistic data, however, were quoted to partly corroborate the assumption of a tripartite family tree. The largest part of the data is taken from the primary corpus languages, some however from less reliable material such as onomastic data.

The East Gmc language branch is assigned to the Gmc tribes that settled in the Eastern part of the Germania during the Roman period. All languages of the East Gmc branch are extinct, their attestations rather sparse. As there is only the Gothic Bible as evidence of any considerable length, EGmc has to be defined on the basis of Gothic, which, in comparison to other Gmc corpus languages, shows some archaic features (cf. 2.4 and 3.5). The main innovations of EGmc are $e>i$ (Goth giba 'gift' vs. OHG geba) and similar heightening tendencies for $\bar{e}_{1}>\bar{l}$ and $\bar{o}>\bar{u}$ (the former more pronounced than the latter), sharpening (Goth twaddje 'of two' vs. OS tueio), Auslautverhärtung, and extensive weakening of final syllables, resulting in syncopated inflectional forms such as Goth dags 'day' <*dagaz.

The North Gmc branch is located in Scandinavia and has a long transmission history, beginning from the earliest runic inscriptions (cf. 2.3). The main language, however, is Old Icelandic, one of the latest attested medieval Gmc dialects. North Gmc is considered to be a rather archaic branch, and its main features developed quite late, i.e. after the extinction of the East Gmc languages (on early $a i>\bar{a} / \ldots h$ cf. 2.3). Its main characteristics are: loss of initial $w$ before $o$ and $u$ (OHG wurtum vs. ON urðu), loss of initial $j$ (OHG jār vs. ON ár), preterite participle with -ina instead of -ana (ON gefinn vs. Goth gibans 'given'; cf. however Nielsen 1989: $8 \mathrm{f}$.) and sharpening (ON tveggja 'of two' vs. OS tueio). Medieval NGmc was strongly exposed to syncope, which, on the one hand, caused several umlaut and breaking rules in stressed syllables and, on the other hand, made the nominative sg. of $a$ - and $i$-stems appear quite similar to those of Goth (ON dagr 'day' vs. Goth dags).

The West Gmc branch, finally, is designated for those areas that were closest to the Roman Empire during the Imperial Age, i.e. mainly the Netherlands, Germany, and Southern Jutland. The situation is more complicated than in East or North Gmc, insofar as West Gmc does not have one "reference language", but at least four, namely OE, OS, $\mathrm{OFr}$, and $\mathrm{OHG}$. These medieval languages are already separated from each other by many significant differences and only kept together by a few common features, the most important of which are: the West Gmc gemination of consonants before $j$ (OE cynn, OHG kunni 'kin' vs. Goth kuni), replacement of the original 2sg. pret. ending (OHG OS $n \bar{a} m i$ vs. Goth ON namt), and the loss of final $-z$ in unstressed syllables (OS dag vs. Goth dags) cf. 4.2 [runic]).

\subsection{Bipartite subgrouping}

One of the earliest attempts at Gmc dialect grouping can be found in Adelung (1809: 175). Adelung, much earlier than Schleicher, sketched a Proto-Gmc family splitting up into two unequal parts, of which one branch consisted of High German only, whereas 
all other languages together belonged to the second branch. The first scholar to express this approach in systematic terms was Rask (1818: $63 \mathrm{ff}$.), who modified Adelung's view by combining High German with Gothic and opposing them both to the Scandinavian languages. It must be added, though, that these early scholars were more interested in tribes and tribal history than in languages, or at least mixed up both aspects (cf. 1.1).

Theories after Schleicher partly combine the binary aspect of a two-branch tree with the idea of a final tripartite grouping. Schwarz (1951: $47 \mathrm{ff}$.) grouped EGmc and NGmc into a Gotho-Nordic (gotonordisch) branch as opposed to WGmc. According to his theory, the Gotho-Nordic branch later on split up into EGmc and NGmc, while WGmc continued to exist. Traditions about the Scandinavian origin and prehistoric migration from Scandinavia to the Continent - especially of Goths and Langobards - seemed to confirm this theory. Schwarz considered common innovations (e.g. sharpening) as well as common archaisms (e.g. $4^{\text {th }}$ class of weak verbs, nom. sg. marker PGmc $*_{-z}$ ) to draw a picture in which Gothic played a quite prominent role compared to Rask's model.

Problems in Schwarz' theory apply to both linguistic and extralinguistic arguments. Apart from the fact that common archaisms do not generally carry conviction, the concrete data are doubtful, too. During the transmission time of Gothic, when $a$ - and $i$-stems had already lost their stem vowel before the ending $-s$ of the nom. sg., the Scandinavian inscriptions still preserve the full $-a z /-i z$ ending. Goth and ON sharpening, which Schwarz used as another argument for a Gotho-Nordic branch of Germanic, did in fact not take place at the same time in both languages. Moreover, even though sharpening describes a similar process in both languages, its results are in part different (Goth twaddje vs. ON tveggja; Petersen 2002). Furthermore, the early medieval literary sources that claim a Scandinavian origin for both Goths and Langobards have been strongly disputed.

Most scholars have therefore rejected the Gotho-Nordic model, the first being Kuhn (1955: $8 \mathrm{ff}$.), who was of the opinion that the parallels between WGmc and NGmc exceeded those between EGmc and NGmc (or rather Goth and ON) and posited a NorthWest-Gmc unity attested as such in the early runic inscriptions (cf. 2.3). This model of "Ausgliederung" looks like a mirror image of the Gotho-Nordic one: Gothic separated from the PGmc continuum first, leaving some kind of remnant Gmc or North-West Gmc behind. Several scholars have followed this idea, some of them with smaller modifications (Antonsen 1975; Makaev 1996; Penzl 1996; Markey 1976: 24). NWGmc is characterized mainly by the following features: $\bar{e}_{1}>\bar{a}$ (OHG jār, ON $a ́ r$ vs. Goth jer 'year'), rhotacism $z>r$ (OHG OS méro, ON meiri vs. Goth maiza 'more'), and phonologically conditioned lowering of $i$ and $u$ (OE OFr OS OHG hold, ON hollr vs. Goth hulps 'gracious').

There are many arguments in favour of the NWGmc theory, but there are also some objections (e.g. Grønvik 1998: $70 \mathrm{ff}$.), the most important one being the WGmc loss of final $-z$. This argument, however, is somewhat circular, and the assumption of an early date for this loss remains a topic of debate (cf. 2.2 and 2.3). Other arguments such as, for example, the opposition of the personal pronoun NGmc $e k$ vs. WGmc $i k$ can be put into perspective by discoveries of NGmc $i k$ and WGmc $e k$ (Nielsen 2000: 158). Antonsen (1975: $26 \mathrm{f}$.), as a solution, suggested that NWGmc covered only the WGmc area to the exclusion of Pre-OHG. This was a step in the right direction, as it comes closer to the reality of a dialectal continuum and dismisses the idea of a homogeneous language area extending over large parts of Europe. 
Vennemann (1984) presented a completely different view of the language history and dialectology of early Gmc which was, however, similar to the early attempts insofar as it resulted in a division of northern vs. southern Gmc. Vennemann's idea was based on the "glottalic theory", which reconstructed a system of PIE glottalized stops * $p$ ' $* t^{\prime} * \hat{k}$ ' $* k$ ' $k^{u}$ ' instead of the traditional $*_{b} * d * g * g *{ }^{\prime}{ }^{u}$ (Gamkrelidze-Ivanov 1995: $5 \mathrm{ff}$.). According to Vennemann, there was only one consonant shift instead of two. This single consonant shift "bifurcated", i.e. had different results in pre-OHG and the rest of the Gmc speaking area and therefore did not separate High and Low German, but High and Low Germanic. This theory has met many objections, not least by its creator (Vennemann 2006).

\subsection{Multipartite subgrouping}

To bypass the problems that resulted from bipartite subgrouping models of Gmc, some scholars tried to find a solution in a multipartite family tree. Grimm was one of the first; he proposed several different views during his scholarly life, like his contemporaries mostly speaking about tribes instead of languages. Most of the newer theories deal with the notorious problem of West Gmc, either denying its existence or modifying the view of its historical reality (cf. 3.4). The main exponent here was Maurer (1952), and his main subject was the relationship between southern Alamanns and northern Scandinavians, which he considered to be closer in an early time than that between the Alamanns and the Frisians, Angles, or Saxons, for example. Maurer explicitly and as part of his methodological concept consulted non-linguistic evidence, i.e. mainly archaeological and historiographical data. Interestingly enough, the family tree depicted by Maurer, is reminiscent of Pliny's description of Germanic tribal grouping (cf. 1.1). This critical view of WGmc is still quite frequent in today's scholarship.

\subsection{West Germanic issues}

Schleicher's WGmc branch definitely does not represent a uniform subgroup, as there are some old differences between the languages. There seems to be a principal distinction between the northern and the southern part of this group; the demarcation between both parts, however, is a matter of controversy. The northern part, North Sea Gmc or Ingvaeonic, is the larger one, but it is a moot point whether Old Saxon and Old Low Franconian really belong to it, and if yes, to what extent they participate in all its characteristic developments.

North Sea Gmc characteristics are most clearly apparent in OE and OFr (AngloFrisian), but it is important to remember that the principal OE dialects - Anglian and West Saxon - sometimes differ considerably. The most important characteristics are (for a comprehensive overview cf. Markey 1976; Nielsen 1985; Krogh 1996: 141 ff.; Nielsen 2001):

1. Fronting of WGmc $\bar{a}$ from Gmc $\bar{e}_{1}(\mathrm{OFr} j \bar{e} r<* j \bar{a} r a)$, which took place only partially in OLF and even less regularly in OS. 
2. Fronting of WGmc $a\left(\mathrm{OE}\right.$ doeg $\left.\mathrm{OFr} d e i<* d a g^{a}\right)$, which took place only partially in OLF and OS.

3. Palatalization of WGmc $g$ and $k$ (OE circe OFr tzierka $<* k i r i k a)$, which occurs a few times in OS, but is less certainly attested in OLF.

4. Loss of nasal before $f, s, p$ with compensatory vowel lengthening (OE OFr $t \bar{o} p<$ *tanpu); this development is also quite consistent in OS and somewhat less frequent in OLF.

5. Uniform inflectional forms occur in the acc. and dat. of the $1^{\text {st }} \mathrm{sg}$. pronoun; this also holds true for both OLF and OS.

6. Uniform inflectional forms for the pret. pl., which also occur in OS, but not in OLF.

As a whole, there are arguments for a close relationship between Anglo-Frisian on the one hand and OS and OLF on the other; there are, however, counter-arguments as well. The question as to whether the common features are old and inherited or have emerged by connections over the North Sea is still controversial.

With respect to 1 ., Anglo-Frisian $\bar{e}$ looks like a direct continuation of PGmc $* \bar{e}_{1}$, which would be an argument against grouping OE and OFr with WGmc. It has been shown, however, that the Anglo-Frisian $\bar{e}$ is a secondary product and that all languages had genuine WGmc $\bar{a}$.

As to 4., a similar process occurs in the Alemannic dialects in the South-West of the German-speaking area, ("Staub's Law"). Wrede (1924) thought that these dialects originally were closely linked to "Ingvaeonic" and that Bavarian (where loss of nasals does not occur) was secondarily Gothicized. Staub's Law in Alemannic, however, has to be seen as an independent process since it happened about 1,000 years later than in North Sea Gmc. Another link looks more promising, as NGmc also has early loss of nasals, even though it occurs only before $s$ and, less regularly, before $f$ (ON gás OE gós vs. OHG gans < PGmc *gans- 'goose'). Moreover, this process seems to be quite early. It is, however, unclear, whether the lack of $n$ in early runic asu- $<* a n s u$ - (cf. 2.3) is due to phonological change or only to a runic convention that did not allow $n$ to be written before homorganic sounds (Nielsen 2000: $247 \mathrm{ff}$.).

OS shares features of Anglo-Frisian and $\mathrm{OHG}$ and almost completely lacks individual characteristics. The linguistic position of OS (and OLF) between Anglo-Frisian and OHG has led to the opinion that both were mixed languages due to Franconian influence that affected them in different ways (Kuhn 1973). Early scholars even reconstructed a German proto-language ("neu-urdeutsch") with OS and OHG as its main branches (Förstemann 1896). In recent years, however, scholars have emphasized the North Sea Gmc character of OS again (Krogh 1996: $398 \mathrm{ff}$.).

\subsection{East $\mathrm{Gmc}$ issues}

East Gmc tribes such as the Goths or Vandals were the main players in the Germanic migration period. As Jordanes describes the Goths as originating from Scandza (which is believed to be a name for Sweden), this tribe was linked with Gotland or with Gøtland on the Swedish mainland (cf. 3.2). Subsequently, other EGmc tribes were linked to Scandinavia in a similar way, as e.g., the Burgundians from Borgund in Norway or the Danish island Bornholm (ON Borgundarholmr OE Burgendaland), or the Vandals from 
Vendel in Sweden or Vendsyssel in Denmark. Indeed, Gothic in some respects matches East Norse features, e.g. the lack of combinatory lowering ( $a$-mutation). It has to be added, however, that these East Norse developments occur at a much later time than the attestation of Gothic (Haugen 1982: 34 ff.; Scardigli 2005).

Gothic is the only corpus language of East Gmc and, therefore, also its referential language. Other supposedly EGmc languages such as Burgundian and Vandalic (not to mention Rugian or the like) are only sparsely attested. "EGmc characteristics" are therefore essentially identical with Gothic characteristics (cf. 2.4). Another language, Crimean Gothic, is attested about 1,000 years later than Gothic, Burgundian, and Vandalic, but, because of forms like geen 'go' and goltz 'gold', its EGmc character is not uncontested, despite its form ada 'egg', which shows a clear EGmc phonology (Stearns 1978; Grønvik 1983).

The early attestations of Burgundian and Vandalic are to a large extent made up of proper names, which as linguistic evidence are quite difficult to handle. Besides the onomastic evidence, there are some legal terms in Latin texts and some loan words. Earlier attempts to prove their EGmc character (Gamillscheg 1936), were rejected (cf. Beck 1978). However, today most scholars again agree with the EGmc character of Burgundian and Vandalic (Francovich-Onesti 2002: 133 ff.; Haubrichs/Pfister 2008).

Two main features are used as arguments in favour of the EGmc character of the proper names: 1. typical lexical elements, such as name constituents; 2 . the endings fem. $-o$ and masc. $-a$ that correlate with the $n$-stem nom. sg. forms of Goth guma 'man' (masc.) and qino (fem.) 'woman'. Furthermore, one Burgundian personal name from the end of the $4^{\text {th }}$ century, Hanhavaldus, has attracted attention: $n$ before $h$ should have disappeared long before and was suspected to be an archaism and, at the same time, a dialectal feature of Burgundian. More probably, however, it is only a Latin writing for nasalized $a$.

Besides attestations in single words, there are some (very) short texts, three of which are 1. the 'Domine miserere', 2. the 'Gothic epigram', and 3. the runic inscription on the fibula from Charnay. 1. and 2. are believed to be Vandalic, 3. Burgundian. 3. contains a verb upfnpai, which is interpreted as an equivalent of the Goth subjunctive form finpai 'he/she may find'. 1. froia arme 'Lord, have mercy' corresponds to Goth *frauja armai. This expression is spelled with Latin letters and the graphs $<_{0}>$ and $<$ e $>$ seem to indicate a monophthongal pronunciation of what in Goth is $<\mathrm{au}>$ and $<\mathrm{ai}>$. However, the evidence of 2. and 3. points the other way, as both the word eils ( Goth hails) in 2., written in the Latin alphabet, and upfnpai in 3., written in runes, contain a diphthongal graphic sequence. These records, however, are quite uncertain: especially 1 . and 2 . might show Vulgar Latin interference.

\section{Abbreviations}

$\begin{array}{llll}\text { Gmc } & \text { Germanic } & \text { NGmc, } \\ \text { PGmc, } & & \text { NWGmc } & \begin{array}{l}\text { North, Northwest } \\ \text { EGmc, }\end{array} \\ \text { WGmc } & \begin{array}{l}\text { Proto, East, West } \\ \text { Germanic }\end{array} & \text { NE, NHG } & \begin{array}{l}\text { New English, New High } \\ \text { German }\end{array}\end{array}$




$\begin{array}{llll}\text { Goth } & \text { Gothic } & \text { OS } & \text { Old Saxon } \\ \text { OE } & \text { Old English } & \text { OFr } & \text { Old Frisian } \\ \text { OHG } & \text { Old High German } & \text { OLF } & \text { Old Low Franconian }\end{array}$

\section{References}

Adelung, Johann C.

1809 Mithridates oder allgemeine Sprachenkunde. Vol II. Berlin: Vosische Buchandlung.

Bandle, Oskar

1973 Gliederung des Nordgermanischen. Basel: Helbing and Lichtenhahn.

Bandle, Oskar, Kurt Braunmüller, Ernst Hakon Jahr, Allan Karker, Hans-Peter Naumann, and Ulf Teleman (eds.)

2002-2005 The Nordic Languages. An International Handbook of the History of the North Germanic Languages. Berlin: De Gruyter.

Beck, Heinrich

1978 Burgunden. In: Beck et al. (eds.), vol. 4., 224-271.

Beck, Heinrich, Dieter Geuenich, Herbert Jankuhn, Hans Kuhn, Kurt Ranke, Heiko Steuer, and Reinhard Wenskus (eds.)

1968-2007 Reallexikon der germanischen Altertumskunde, begrundet von Johannes Hoops. $2^{\text {nd }}$ edition. 35 vols. Berlin: De Gruyter.

Boutkan, Dirk

1995 The Germanic 'Auslautgesetze'. (Leiden Studies in Indo-European 4). Amsterdam: Rodopi.

Van Bree, Cor

1998 The Strange Simplicity of Gothic. Northwestern European Language Evolution 34: 6775.

Bruckner, Wilhelm

1895 Die Sprache der Langobarden. Strassburg: Trübner.

Förstemann, Ernst

1896 Alt-, mittel-, neuurdeutsch. Zeitschrift für vergleichende Sprachforschung 18: 161-186.

Francovich Onesti, Nicoletta

1999 Vestigia Langobarde in Italia (568-774). Lessico e antroponimia. Rome: Artemide.

Francovich Onesti, Nicoletta

2002 I Vandali. Lingua e storia. Rome: Carocci.

Frings, Theodor

1932 Germania Romana. Halle: Niemeyer.

Fritz, Matthias

2011 Der Dual im Indogermanischen. Genealogischer und typologischer Vergleich einer grammatischen Kategorie im Wandel. Heidelberg: Winter.

Gamillscheg, Ernst

1936 Romania Germanica. Vol. 3. Die Burgunder. Berlin: De Gruyter.

Gamkrelidze, Thomas V. and Vjačeslav V. Ivanov

1995 Indo-European and the Indo-Europeans: A reconstruction and historical analysis of a proto-language and a proto-culture, 2 volumes. [Translation of Indoevropejskij jazyk $i$ Indoevropejcy. Rekonstrukcija i istoriko-tipologičeskij analiz prajazyka i protokul'tury. 1984. by Johanna Nichols]. Berlin: Mouton de Gruyter.

Green, Dennis. H.

1998 Language and History in the Early Germanic World. Cambridge: Cambridge University Press. 
Grønvik, Ottar

1983 Die dialektgeographische Stellung des Krimgotischen und die krimgotische cantilena. Oslo: Universitetsforlaget.

Grønvik, Ottar

1998 Untersuchungen zur älteren nordischen Sprachgeschichte. Frankfurt: Lang.

Harbert, Wayne

2007 The Germanic Languages. Cambridge: Cambridge University Press.

Haubrichs, Wolfgang and Max Pfister

2008 Burgundisch (Burgundian). In: Ulrich Ammon and Harald Haarmann (eds.), Wieser Enzyklopädie der Sprachen Westeuropas. Klagenfurt: Wieser, 73-80.

Haugen, Einar

1982 Scandinavian Language Structures. A Comparative Historical Survey. Tübingen: Niemeyer.

Hill, Eugen

2010 A case study in grammaticalized inflectional morphology: Origin and development of the Germanic weak preterite. Diachronica 27: 411-458.

Höfler, Otto

1955 Stammbaumtheorie, Wellentheorie, Entfaltungstheorie. Beiträge zur Geschichte der deutschen Sprache und Literatur (Tübingen) 77: 30-66, 424-476, 78: 1-44.

Howell, Robert B.

1991 Old English breaking and its Germanic analogues. Tübingen: Niemeyer.

König, Ekkehard and Johan van der Auwera (eds.)

1994 The Germanic Languages. London: Routledge.

Kortlandt, Frederik

2006 The Inflection of the Germanic n-Stems. In: Northwestern European Language Evolution 48: 3-7.

Krause, Wolfgang

1971 Die Sprache der urnordischen Runeninschriften. Heidelberg: Winter.

Krogh, Steffen

1996 Die Stellung des Altsächsischen im Rahmen der germanischen Sprachen. (Studien zum Althochdeutschen 29). Göttingen: Vandenhoeck \& Ruprecht.

Kufner, Herbert L.

1972 The grouping and separation of the Germanic languages. In: Frans van Coetsem and Herbert L. Kufner (eds.), Toward a Grammar of Proto-Germanic. Tübingen: Niemeyer, 71-98.

Kuhn, Hans

1955 Zur Gliederung der germanischen Sprachen. Zeitschrift für Deutsches Altertum und deutsche Literatur 86: 1-47.

Kuhn, Hans

1973 Altsächsische Sprache. In: Beck et. al. (eds.), vol. 1, 239-241.

Looijenga, Tineke

2003 Texts and Contexts of the Oldest Runic Inscriptions. Leiden: Brill.

Makaev, Enver A.

1996 The Language of the Oldest Runic Inscriptions. Translation of Jazyk drevnejšix runičeskix nadpisej (1965) by J. Meredig in consultation with E. H. Antonsen. Stockholm: Kunglinga Vitterhets Historie och Antikvitets Akademien.

Marchand, James W.

1959 Names of Germanic Origin in Latin and Romance Sources in the Study of Germanic Philology. Names 7: 167-181.

Markey, Thomas L.

1976 Germanic Dialect Grouping and the Position of Ingvaeonic. Innsbruck: Institut für Sprachwissenschaft der Universität. 
Maurer, Friedrich

1952 Nordgermanen und Alamannen. $3^{\text {rd }}$ edn. Bern: Francke.

Mees, Bernard

2006 Early Rhineland Germanic. Northwestern European Language Evolution 49: 13-49.

Müller, Stefan

2007 Zum Germanischen aus laryngaltheoretischer Sicht. Mit einer Einführung in die Grundlagen. Berlin: De Gruyter.

Munske, Horst Haider (ed.)

2001 Handbuch des Friesischen / Handbook of Frisian Studies. Produced in collaboration with Nils Århammar, Volkert F. Falktings, Jarich Hoekstra, Oebele Vries, Alastair G. H. Walker, and Ommo Wilts. Tübingen: Niemeyer.

Naumann, Hans-Peter (ed.)

2004 Alamannien und der Norden. Internationales Symposium vom 18.-20. Oktober 2001 in Zürich. Berlin: De Gruyter

Neumann, Günter

1993 Sualiternicum 'Bernstein'. In: Klaus R. Grunda and Claus-Dieter Wetzel (eds), AngloSaxonica. Festschrift für Hans Schabram zum 65. Geburtstag. Munich: Fink, 431-439.

Nedoma, Robert

2005 Urnordisch -a im Nominativ Singularis der maskulinen $n$-Stamme. Northwestern European Language Evolution 46/47 (= Papers on Scandinavian and Germanic Language and Culture. Published in Honour of Michael Barnes on his Sixty-Fifth Birthday 28 June 2005), 155-191.

Nielsen, Hans Frede

1985 Old English and the Continental Germanic Languages. $2^{\text {nd }}$ edn. Innsbruck: Institut für Sprachwissenschaft der Universität.

Nielsen, Hans Frede

1989 The Germanic Languages: origins and early dialectal interrelations. Tuscaloosa, AL: University of Alabama Press. (Translation and update of his 1979 De germanske sprog.)

Nielsen, Hans Frede

2000 The Early Runic Language of Scandinavia. Studies in Germanic Dialect Geography. Heidelberg: Winter.

Nielsen, Hans Frede

2001 Frisian and the Grouping of the Older Germanic Languages. In: Munske et al. (eds.), $512-523$.

Nielsen, Hans Frede

2004 Friedrich Maurer and the Dialectal Links of Upper German to Nordic. In: Naumann (ed.), 12-28.

Penzl, Herbert

1996 Ist das nordisch-westgermanische Runengermanisch das 'Ur-Altenglische'? Northwestern European Language Evolution 27: 137-145.

Petersen, Hjalmar P.

2002 Verschärfung in Old Norse and Gothic. Arkiv för Nordisk Filologi 117: 5-27.

Van Pottelberge, Jeroen

2003 Die ursprünglichen Fragestellungen hinter August Schleichers Stammbaum-Theorie und Johannes Schmidts Wellenmetapher. Historiographia Linguistica 30: 301-364.

Rask, Rasmus K.

1818 Undersögelse om det gamle Nordiske eller Islandske Sprogs Oprindelse [An investigation of the origin of the ancient Scandinavian or Icelandic language]. Copenhagen: Gyldendal.

Reichert, Helmut

2003 Personennamen bei antiken Autoren als Zeugnisse für älteste westgermanische Endungen. Zeitschrift für deutsches Altertum 132: 85-100. 


\section{Ringe, Don}

2006 From Proto-Indo-European to Proto-Germanic. (A Linguistic History of English 1). Oxford: Oxford University Press.

Robinson, Orrin W.

1992 Old English and its Closest relatives. A Survey of the Earliest Germanic Languages. Stanford: Stanford University Press.

Scardigli, Piergiuseppe

2005 Nordic-Gothic Linguistic Relations. In: Bandle et al. (eds.), 553-558.

Schleicher, August

1869 Die deutsche Sprache. $2^{\text {nd }}$ edn. Stuttgart: Cotta.

Schmidt, Christoph G., Robert Nedoma, and Klaus Düwel

2011 Die Runeninschrift auf dem Kamm von Frienstedt, Stadt Erfurt. Die Sprache 49: 123186.

Schwarz, Ernst

1951 Goten, Nordgermanen, Angelsachsen: Studien zur Ausgliederung der germanischen Sprachen. Bern: Francke.

Seebold, Elmar

2004 Alemannisch und Nordgermanisch. In: Naumann (ed.), 1-11.

Stearns, MacDonald Jr.

1978 Crimean Gothic: Analysis and Etymology of the Corpus. Saratoga, CA: Anma Libri.

Vennemann, Theo

1984 Hochgermanisch und Niedergermanisch: Die Verzweigungstheorie der germanisch-deutschen Lautverschiebungen. Beiträge zur Geschichte der deutschen Sprache und Literatur 106: 1-45.

Vennemann, Theo

2006 Grimm's Law and Loanwords. Transactions of the Philological Society 104: 129-166.

Vennemann, Theo

1981 Gothic, Germanic, and Northwest Germanic. Wiesbaden: Steiner.

Vennemann, Theo

1992 Early Germanic Grammar: Pre-, Proto- and Post-Germanic languages. San Diego: Academic Press.

Wagner, Norbert

1989 Der Stammesname der Salier und die ,westgermanische“ Konsonantengemination. Zeitschrift für deutsches Altertum 118: 34-42.

Wrede, Ferdinand

1924 Ingwäonisch und Westgermanisch. Zeitschrift für deutsche Mundarten 19: 270-283.

Ludwig Rübekeil, Zürich (Switzerland)

\section{The evolution of Germanic}

1. Introduction

2. The range and internal structure of Germanic

3. Phonological patterns

4. Morphological patterns
5. Syntactic patterns

6. Conclusion: Conservatism and paths of innovation

7. References

https://doi.org/10.1515/9783110523874-014 